\title{
Recent ruling exposes leniency of Brazilian Courts to police violence
}

\author{
Alexandre Leal*
}

On August 9, 2017 the Court of Appeals of the State of São Paulo, in Brazil, absolved police officers of allegations of torture, claiming the infliction of physical and psychological pain was not used with the purpose of obtaining a confession, information or statement about a crime.

The facts of the case date back to 2003 . Police officers investigating a kidnapping entered a house in the outskirts of São Paulo in search of the victim. A middleaged woman and a child were in the house and told the police that they did not have any information about the crime or know where the victim was. The following night, the kidnapped victim managed to escape and get help from police officers who were patrolling the area. It turned out that the victim was being held in a bedroom in a house adjacent to the one police officers had visited.

Police officers then returned to the house, although they did not have a warrant. They allegedly "knocked the middle-aged woman in the face" and "used offensive language against her". They also supposedly beat up a female neighbour who "insisted on looking at what was happening." This woman was pregnant and lost the baby a week later. Police officers arrested the middle-aged woman, her husband and a third male using violence, locking them in a jail cell where tear gas was thrown in twice, while verbal threats and physical beatings took place. ${ }^{1}$

The Court ruling

The court took the view that, while it was likely that the police officers used some violence, state officials had not explicitly asked for a confession, statement or declaration from the victims. This was found on the basis of the testimonies, despite one of the plaintiffs stating "he was physically and verbally assaulted by the police when being put inside the police car [...] while officers called him the mastermind of a kidnapping."

It was also found that the evidence did not show that the physical violence had been intense enough to be characterized as torture, or that there was any psychological torture. The court admitted the narrative and evidence pointed to "some excesses" in the operation, which could be characterized as infractions of abuse of police power and infliction of bodily injuries, but this conduct did not amount to torture.

It was also found that there was no clear causal link between the actions of police officers and the neighbouring woman's miscarriage.

The Court's opinion is available in Portuguese at https://www.conjur.com.br/dl/agressao-policialobjetivo-confissao.pdf. 
Concerning the psychiatric harm experienced by another plaintiff, the Court understood they were a natural "development of the situation as a whole, considering she was arrested without a warrant, for a crime she did not commit, and detained as a suspect of kidnapping."

\section{Shortcomings of the Court's decision}

The decision was subject to much criticism. ${ }^{2}$ Police offers' actions are not held sufficiently accountable for their actions and the ruling clearly impedes the reduction of police brutality and protection of human rights, especially those related to the prevention, reparation and accountability of torture in Brazil.

The Court's interpretation of torture reduces its scope and application to a limited nature of cases, negating national and international definitions of torture, and implying that state officials would have to explicitly enunciate that their violent acts are perpetrated with the purpose of obtaining a confession or declaration from the victim.

The decision disregards the domestic law that states torture can also be motivated by "discrimination", or the intention to "apply personal punishment or preventive measures" (Law 9455/97) ${ }^{3}$. Likewise, it neglects the Convention Against Torture, ratified by Brazil, which sets out in Article 1 that torture is inflicted on a person also to "punish him (sic) for an act he (sic) or a

2 Consultor Juridico, "Agressão policial sem objetivo de obter confissão não é tortura, diz TJ-SP” [Aggression by police authorities with no aim to obtain a confession is not torture, São Paulo State Court rules"]. Available in Portuguese at: http://www.conjur.com.br/2017-set-19/agressaopolicial-objetivo-confissao-nao-tortura-tj-sp

3 Available in Portuguese at http://www.planalto. gov.br/ccivil_03/leis/19455.htm third person has committed or is suspected of having committed."

The decision further highlights a considerable gap in the Brazilian institutional structure for combatting torture. Since its democratization, Brazil has not yet built capacity to investigate and respond to torture cases. Forensic institutes are subordinated to the police (if not legally, de facto), and modern tools to investigate and document torture like the Istanbul Protocol are marginally, if at all, applied in the country. In this case, the Court overruled the plaintiffs' claims by making superficial assessments on the severity of physical and mental pain inflicted on them. Such conclusions can only be meaningfully reached with the assistance of an independent multidisciplinary team, including medical doctors and psychiatrists, according to the internationally applied guidelines of the Istanbul Protocol. ${ }^{4}$

Since 2003, when the facts referred to above took place, some progress has in fact been made, partly due to several critical reports issued by the United Nations. ${ }^{5}$ 'Custody hearings' were established, in which individuals are brought to court immediately after their arrest and judges are asked to check for signs of torture. Likewise, a National Mechanism for the Prevention and Combating of Torture was created, allowing authorities to visit facilities, issue reports, and follow up on court cases, which should increase accountability from both the Executive and the Judicial Branches.

4 Manual on Effective Investigation and Documentation of Torture and Other Cruel, Inhuman, or Degrading Treatment or Punishment, 1999, United Nations.

5 See for example UN reports: A/HRC/31/57 and E/CN.4/2006/6/Add.2. 
At the same time, since before the country's last Universal Periodic Review in 2017 , civil society has repeatedly called attention to the spike in occurrences of police violence, with increasingly aggressive tactics and a rising number of extrajudicial killings by state authorities, largely aggravated by a climate of impunity. ${ }^{6}$ Brazil has been called upon to "strengthen prevention and effectiveness of investigation of cases of police violence."7

6 Amnesty International "Brazil: Police Killings, Impunity and Attacks on Defenders", submission to the UPR Review in May 2017. Available at: https:/www.amnesty.org/download/Documents/ AMR1954672016ENGLISH.pdf

7 For a full list of UPR recommendations see https://www.upr-info.org/sites/default/files/document/brazil/session_27_-_may_2017/response_to_ recommendations_brazil_2017.pdf . 